УДК 553.98:550.8:551.76:552.5(571.62)

\title{
ГЕОТЕРМИЯ И ОЦЕНКА НЕФТЕГАЗОВОГО ПОТЕНЦИАЛА БУРЕИНСКОГО БАССЕЙНА (ДАЛЬНИЙ ВОСТОК РОССИИ)
}

\author{
Прохорова Полина Николаевна',
} prokhorova.polina1988@gmail.com

Развозжаева Елена Петровна²,

rep@itig.as.khb.ru

\author{
Исаев Валерий Иванович', \\ isaevvi@tpu.ru

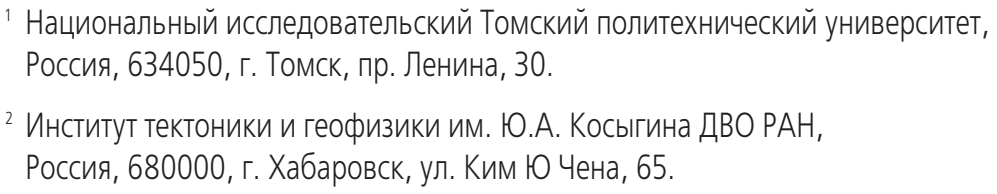

Актуальность. Буреинский осадочный бассейн - наиболее интересная в нефтегазоносном отношении межгорная впадина слабоизученной материковой части Дальнего Востока России. Положительная оценка в отношении перспектив обнаружения в отложениях бассейна месторождений нефти и газа обоснована результатами ранее проведённых производственных и научных работ. Цель: дальнейшая аргументация перспектив нефтегазоносности верхнеюрско-нижнемеловых отложений Буреинского бассейна на основе применения отечественного программного обеспечения бассейнового моделирования TeploDialog, обладающего оригинальными особенностями.

Объект: осадочные комплексы средне-верхнеюрский, верхнеюрско-нижнемеловой и меловой Кындалского грабена, наиболее хорошо изученной структуры в составе Буреинского краевого прогиба. Ранее проведенные исследования показали, что в процесс нефтегазообразования вовлечён весь юрско-меловой разрез Буреинского бассейна.

Методы. В комплексе TeploDialog реализован метод палеотемпературного моделирования, основанный на численном решении уравнения теплопроводности горизонтально-слоистого твердого тела с подвижной верхней границей. В математическую модель непосредственно включены климатический вековой ход температур на земной поверхности, как краевое условие, и палеотемпературы из определений отражательной способности витринита, как «наблюденные». Метод не требует априорных сведений о природе и величинах глубинного теплового потока, поток определяется решением обратной задачи геотермии в рамках параметрического описания седиментационной истории и истории теплофизических свойств осадочной толщи.

Результаты. Установлено, что геотермия грабена, начиная с юрского времени, благоприятствовала процессам генерации жидких углеводородов в породах осадочного чехла, которые могли начаться около 107 млн лет назад, в середине альба. Наиболее интенсивно нефтегенерация происходила в период 107-40 млн лет назад, до середины эоцена. Температурные условия генерации жидких углеводородов сохраняются для талынджанского очага. Наибольшая продолжительность температурных периодов, благоприятных для газообразования, наблюдается в чемчукинском очаге. Условия генерации газа сохраняются для ургальского и чагдомынского очагов. Результаты, полученные с использованием отечественной системы TeploDialog и ранее полученные в системе PetroMod, во многом совпадают. Названные системы характеризуются разными подходами к рассмотрению тектоно-седиментационных и термических условий генерации УВ. Поэтому результаты настоящих исследований являются дополнительной аргументацией положительных перспектив нефтегазоносности верхнеюрско-нижнемеловых отложений Буреинского бассейна.

\section{Ключевые слова:}

Верхнеюрско-нижнемеловые отложения, геотермический режим, очаги генерации углеводородов,

Буреинский осадочный бассейн, Дальний Восток России.

\section{Введение}

Верхнебуреинская впадина (Буреинский осадочный бассейн) - одна из наиболее интересных в нефтегазоносном отношении межгорных впадин южной части материка в Дальневосточном регионе $[1,2]$.

Положительная оценка в отношении перспектив обнаружения в отложениях Буреинского бассейна месторождений нефти и газа обоснована результатами ранее проведённых работ по изучению его геологического строения, нефтегазоносности, газогеохимии и подземных вод [3].

В настоящее время при решении задач, связанных с прогнозом нефтегазоносности, широко применяется бассейновое моделирование [4-6]. Этот процесс можно разделить на две относительно независимые части: моделирование истории погру- жения, тектоники, термического развития (первая часть) и моделирования процессов генерации, миграции, аккумуляции и сохранности углеводородов (УВ) в бассейне (вторая часть). Первая часть в зарубежной литературе определена термином «бассейновое моделирование» («basin modeling»), вторая - «моделирование углеводородных систем» («petroleum system modeling»). Можно придерживаться этой терминологии.

Количество генерированных УВ рассчитывается на основе реконструкции геотемпературного режима нефтематеринских отложений. На региональном этапе геологоразведочных работ технология бассейнового моделирования позволяет выделить очаги генерации УВ и проследить их динамику на протяжении эволюции бассейна. Существую- 
щие на сегодняшний день программно-математические комплексы бассейнового моделирования (ГАЛА, Тетіs и др.) характеризуются разными подходами к рассмотрению тектоно-седиментационных и термических условий генерации УВ в бассейне $[7,8]$.

Первая и единственная оценка реализации генерационного потенциала нефтематеринских отложений Буреинского бассейна в пределах Кындалского грабена с помощью программного комплекса бассейнового моделирования представлена в работе [9]. Моделирование выполнено с применением программного обеспечения PetroMod 1D компании Шлюмберже.

Цель настоящей работы - дальнейшая аргументация перспектив нефтегазоносности верхнеюрско-нижнемеловых отложений Буреинского бассейна на основе применения отечественного программного обеспечения бассейнового моделирования TeploDialog, обладающего оригинальными превосходными особенностями.

Достижение поставленной цели осуществлялось путем решения следующих задач: 1) актуализация геолого-геофизических, геохимических и нефтегеологических данных в пределах Кындалского грабена; 2) одномерное моделирование глубинного теплового потока и термической истории потенциально нефтегазоматеринских свит; 3) выделение по геотемпературному критерию очагов генерации нефти и газа; 4) оценка времени и интенсивности реализации фаз нефте- и газообразования органическим веществом нефтегазоматеринских отложений.

\section{О методике исследований}

Оценка реализации генерационного потенциала нефтегазоматеринских пород в пределах Кындалского грабена выполнена с помощью комплекса TeploDialog. В комплексе реализован метод палеотемпературного моделирования, основанный на численном решении уравнения теплопроводности горизонтально-слоистого твердого тела с подвижной верхней границей [10]. Метод опирается на решение прямой задачи геотермии, как частный случай найденных решений для набора горизонтальных бесконечных плоскопараллельных слоев, расположенных в нижнем полупространстве [11].

Расчет палеотемператур состоит из двух этапов. На первом, по распределению температур, «наблюденных» в скважине, рассчитывается тепловой поток через поверхность основания осадочного чехла, т. е. решается обратная задача геотермии. На втором этапе, с известным значением теплового потока, решаются прямые задачи геотермии - рассчитываются температуры в заданных точках осадочной толщи (в том числе в материнских отложениях) на заданные моменты геологического времени.

В математическую модель непосредственно включены палеотемпературы из определений отражательной способности витринита (ОСВ), как «наблюденные». Для перехода от ОСВ к соответствующей геотемпературе используется диаграмма «Линии значений отражательной способности витринита, нанесенные на измененную схему Коннона» [12].

Отличия TeploDialog и PetroMod заключаются в разных подходах к определению граничных условий при моделировании тектонической и тепловой истории отложений осадочного бассейна.

Нижним граничным условием является значение теплового потока из основания бассейна осадконакопления. При моделировании в PetroMod предусматриваются переменные значения плотности теплового потока из основания осадочного чехла, определяемые на основе модели растяжения двухслойной литосферы Маккензи [13]. При палеотемпературном моделировании в TeploDialog предполагается квазипостоянство значения плотности теплового потока из основания. B TeploDia$\log$ глубинный тепловой поток определяется решением обратной задачи геотермии, в рамках параметрического описания седиментационной истории и истории теплофизических свойств только осадочной толщи, без привлечения сведений о геодинамике ниже основания осадочного разреза.

Верхнее граничное условие - вековой ход поверхностных температур на протяжении моделируемого отрезка истории развития бассейна. В отличие от TeploDialog, в котором используются экспериментальные данные о вековом ходе температур на земной поверхности $[14,15]$, в PetroMod peализован теоретический расчёт поверхностных палеотемператур на основе значений палеошироты территории исследований, определяющей интенсивность солярного источника тепла [4].

В методическом подходе, использующем TeploDialog, применяется простой способ (эксперессрасчет) интегрального показателя генерации УВ. Расчет реализуется следующим образом. Решение прямых задач геотермии выполняется на моменты геологического времени, включающие времена начала/завершения формирования каждой свиты, перекрывающей материнскую. Балансовая модель процессов нефтегазообразования [16] позволяет по геотемпературному критерию выполнить выделение очагов интенсивного образования УВ из рассеянного органического вещества (РОВ) материнских отложений. Далее для материнской свиты рассчитывается интегральный показатель плотности генерации углеводородов $R$ [17]. Расчетное значение $R$ напрямую зависит от времени нахождения материнской свиты в «верхней зоне газообразования» (ВЗГ), «главной зоне нефтеобразования» $(Г З Н)$, «нижней зоне газообразования» (НЗГ) и от геотемператур этих зон. Применяемый подход позволяет кумулятивно учитывать динамику геотемператур материнских отложений и достаточно просто выполнять пространственно-временную локализацию очагов генерации УВ. 


\section{Краткая характеристика территории исследований}

В строении осадочного чехла Буреинского бассейна принимают участие четыре комплекса: нижне-среднеюрский (дешская $d s$, синкальтинская $s n$, эпиканская $e p$, эльгинская $e l$ свиты), средневерхнеюрский (чаганыйская $c g$, талынджанская $t l$ свиты), верхеюрско-нижнемеловой (ургальская $u r$, чагдамынская $c g$, чемчукинская $\mathrm{cm}$, йорекская ir свиты) и меловой (кындалская $k n$ свита и песчаниковая $p s$ толща).
Кындалская грабен-синклиналь является наиболее хорошо изученной структурой в составе Буреинского краевого прогиба (рис. 1).

Кындалский грабен расположен в центральной части Кындалской грабен-синклинали, имеет север-северовосточную протяженность, около 56 км в длину при максимальной ширине до 17 км. В целом осадочный разрез грабена представлен ритмичным переслаиванием песчаников, алевролитов, аргиллитов, реже конгломератов, с редкими пластами углей и прослоями туфов.
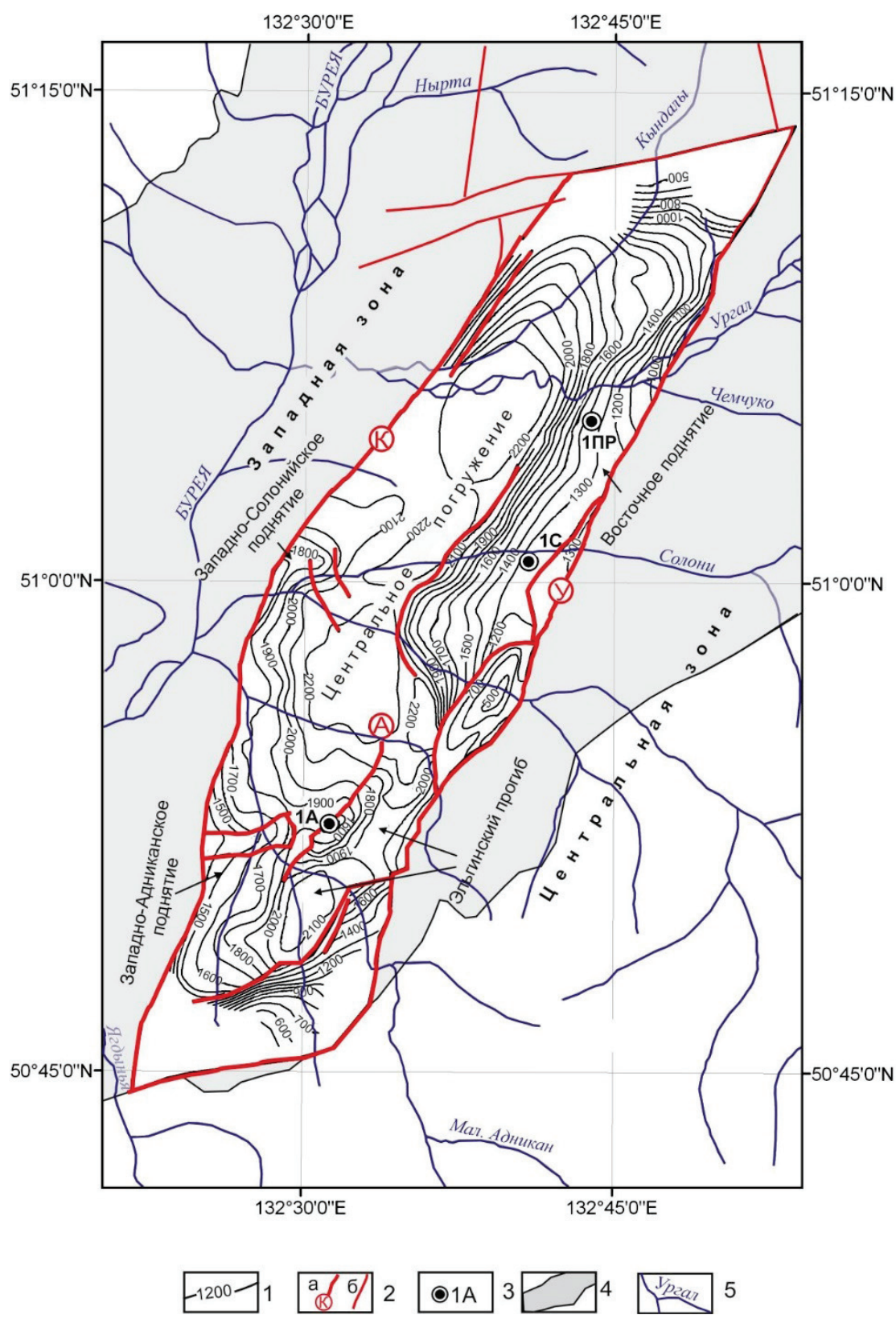

Pис. 1. Структурная схема Кындалского грабена (по подошве йорекской свиты): 1 - изоглубины подошвы йорекской свиты, л; 2 - разломы: а) главные и их буквенное обозначение ( $K$ - Кьндалский, У - Ургальский, $A-A$ - Анканский $),$ б) второстепенные; 3 - глубокие скважины, по которыл проводилось моделирование; 4 - территория Кындалской грабен-синклинали; 5 - гидросеть

Fig. 1. Structure map of Kyndal graben (from the bottom of iorekskaya suite): 1 - isodepth of iorekskaya suite bottom, m; 2 - faults: a) main and their letter identification ( $K$ - Kindalskiy, U - Urgalskiy, A-Adnikanskiy), b) affluent; 3 - deep wells that were modeled; 4 - Kyndal Graben-synclinal area; 5 - hydrographic network 
В период с 1965 по 1972 гг. в пределах Кындалского грабена проведено структурно-картировочное, параметрическое и поисковое бурение шести скважин, в том числе одной параметрической $1 П Р$ на Восточном поднятии. Почти по всему осадочному разрезу были зафиксированы многочисленные проявления УВ, но промышленных скоплений не обнаружено. В 1980-1990 гг. пробурены две глубокие скважины: 1С в центральной части и $1 \mathrm{~A}$ в его южной части грабена. В скважине $1 \mathrm{~A}$ получены промышленные притоки газа, что послужило открытию Адниканского газового месторождения.

В 1990-х гг. в разрезе скважины 1А, вскрывшей чагдамынскую, чемчукинскую, йорекскую, кындалскую свиты и песчаниковую толщу, проведено детальное изучение литологии, фильтрационно-емкостных свойств пород и геохимии органического вещества. По результатам исследований выявлено, что в процесс нефтегазообразования вовлечён весь юрско-меловой разрез Буреинского осадочного бассейна, при этом исходное органическое вещество имеет преимущественно гумусовый состав [3].

Глубокие скважины $1 \mathrm{~A}, 1 \mathrm{C}$ и 1 ПР расположены соответственно в южной (Адниканская антиклинальная структура), центральной и северо-восточной (Восточное поднятие) частях грабена (рис. 1).

Далее приводятся краткие сведения о мощности вскрытого разреза, возрастной привязке, наличии размыва, измеренных значениях показателя OCB, а также результатах испытаний верхнеюрско-меловых пластов. Данные испытаний скважин $1 \mathrm{~A}$ и $1 \mathrm{C}$ изучены и сведены из первичных «дел скважин» (материалы Хабаровского филиала ФБУ «Территориальный фонд геологической информации по Дальневосточному федеральному округу»), данные испытаний скважины 1ПР приняты из монографии [3], значения ОСВ $\left(R_{v t}^{0}\right)$ приняты из названной монографии.

Скважина 1А. На забое (2998 м) ургальская свита $\left(J_{3}-K_{1}\right)$, вскрытая на глубине 2600 м. Фиксируется перерыв осадконакопления в раннем мелу, размыв позднемеловых и палеоген-неогеновых отложений. Результаты испытаний кындалской свиты $\left(K_{1-2}\right)$ : 438-455 м, фонтанный газ, 53 тыс. $\mathrm{m}^{3} /$ сут; $993-1010 \mathrm{м}, \quad$ газ, 82 тыс. $\mathrm{M}^{3} /$ сут; 1118-1140 м, вода+растворенный газ, 11 м $^{3}$ сут. Результаты испытаний йорекской свиты $\left(K_{1}\right)$ : 1202-1215 м, вода+растворенный газ, $7 \mathrm{~m}^{3} /$ сут; 1218-1225 м, вода+растворенный газ, $7 \mathrm{~m}^{3} /$ сут. Температуры, определенные по ОСВ: 1888 м, $99^{\circ} \mathrm{C}$ $\left(R_{v t}^{0}=0,64\right) ; 2196 \mathrm{~m}, 114^{\circ} \mathrm{C}\left(R_{v t}^{0}=0,75\right)$.

Скважина 1C. На забое (3459 м) талынджанская свита $\left(J_{3}\right)$, вскрытая на глубине 2863 м. Фиксируются перерывы осадконакопления в поздней юре и раннем мелу, размыв позднемеловых и палеоген-неогеновых отложений. Результаты испытаний чемчукинской свиты $\left(K_{1}\right): 1638-1649$ м, слабогазированный фильтрат бурового раствора с пленкой нефти. Результаты испытаний ургальской свиты: 2680-2792 м, слабогазированный фильтрат бурового раствора. Температуры, определенные по ОСВ: $1211 \mathrm{~m}, 83{ }^{\circ} \mathrm{C}\left(R_{v t}^{0}=0,52\right) ; 1263 \mathrm{м}$, $83{ }^{\circ} \mathrm{C}\left(R_{v t}^{0}=0,52\right) ; 1355 \mathrm{~m}, 84^{\circ} \mathrm{C}\left(R_{v t}^{0}=0,53\right)$.

Скважина 1ПР. На забое (3012 м) ургальская свита $\left(J_{3}-K_{1}\right)$, вскрытая на глубине 2570 м. Фиксируется перерыв осадконакопления в раннем мелу, размыв позднемеловых и палеоген-неогеновых отложений. Имели место повышенные газопоказания при проходке кындальской, чемчукинской и чагдамынской свит. При проходке ургальской свиты в интервале 2720-3002 м наблюдались выбросы нафтено-метановой парафинистой нефти. Результаты испытаний ургальской свиты: 2941-2966 м, газ, $500 \mathrm{~m}^{3} /$ сут.

\section{Параметризация и моделирование}

Палеореконструкции истории погружения и геотемператур выполнены для трех глубоких скважин: $1 \mathrm{~A}, 1 \mathrm{C}$ и 1ПР Кындалского грабена (рис. 1). Пример параметризации тектоно-седиментационной истории и теплофизических свойств осадочного разреза показан в табл. 1 .

Термическая история осадочных комплексов восстанавливалась на основе использования фактических данных об ОСВ. Отражательная способность витринита - природного максимального термометра, наиболее предпочтительна для восстановления тепловой истории отложений, так как отражает кумулятивный эффект воздействия температур на РОВ [19, 20].

Скважина 1А пересекает аллохтонный и автохтонный блоки Адниканского надвига на глубине около 1850 м. Предварительный анализ показал, что значения показателя ОСВ для отложений висячего блока являются некондиционными. Для моделирования были отобраны значения показателя $\mathrm{OCB}$, измеренные в образцах керна скважины с глубины ниже $1850 \mathrm{~m}$.

Для скважины $1 \mathrm{C}$ для моделирования были выбраны значения показателя ОСВ по двум структурно-картировочным скважинам 14 -ск и 16 -ск, расположенным в аналогичных структурно-тектонических условиях.

Для скважины 1ПР измеренные значения показателя ОСВ отсутствуют. Построение модели геотемператур выполнялось на основе экстраполяции рассчитанных величин теплового потока, полученных в скважинах $1 \mathrm{~A}$ и $1 \mathrm{C}$.

Применение вариативности [21] сценариев тектоно-седиментационной истории и реконструкций геотермического режима осадочного разреза позволили количественно определить мощность денудации в меловое время (табл. 1).

Контроль результатов моделирования осуществлялся сопоставлением «измеренных» и расчетных геотемператур в скважинах (табл. 2). Среднеквадратические отклонения фактических значений от расчетных составили $\pm 2-3{ }^{\circ} \mathrm{C}$. Такие «невязки» оптимальны [22], т. к. «наблюденные» геотемпературы (OCB) имеют погрешность определения порядка $\pm 2{ }^{\circ} \mathrm{C}[10]$. 
таблица 1. Пример паралетризации осадочной толщи для моделирования (скважина 1А)

Table 1. Example of parameterization of sedimentary strata for modeling (well 1A)

\begin{tabular}{|c|c|c|c|c|c|c|c|}
\hline $\begin{array}{l}\text { Свита, толща (стратиграфия)* } \\
\text { Suite, strata (stratigraphy)* }\end{array}$ & $\begin{array}{c}\text { Мощность, } \\
\text { м* } \\
\text { Thickness, } \\
\text { m* }\end{array}$ & $\begin{array}{c}\text { Возраст, млн } \\
\text { лет назад** } \\
\text { Age, million ye- } \\
\text { ars ago } * *\end{array}$ & $\begin{array}{c}\text { Время накопле- } \\
\text { ния, млн лет } \\
\text { Time, million } \\
\text { years } \\
\end{array}$ & 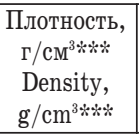 & \begin{tabular}{|c|} 
Теплопровод- \\
ность, Вт/м·град \\
Thermal conducti- \\
vity, $\mathrm{W} / \mathrm{m} \cdot \mathrm{deg}$ \\
\end{tabular} & $\begin{array}{c}\text { Tемпературопро- } \\
\text { водность, } \mathrm{m}^{2} / \mathrm{c} \\
\text { Heat diffusivity, } \\
\mathrm{m}^{2} / \mathrm{s}\end{array}$ & \begin{tabular}{|c} 
Тепловыделе- \\
ние, Вт/м ${ }^{3}$ \\
Heat produc- \\
tion, $\mathrm{W} / \mathrm{m}^{3}$ \\
\end{tabular} \\
\hline $\begin{array}{c}\text { Квартер } \\
\text { Quaternary system } Q\end{array}$ & 30 & $0-1,81$ & 1,81 & 1,6 & 0,91 & $6,5 \mathrm{e}-007$ & $1,1 \mathrm{e}-006$ \\
\hline$p_{1}-N_{2}$ & -200 & $1,8-61,7$ & 59,89 & 1,9 & 1,17 & $6,5 e-007$ & $1,1 \mathrm{e}-006$ \\
\hline $\begin{array}{c}\text { Песчаная } \\
\text { Peschanaya } p K_{2}-\boldsymbol{p}_{1}\end{array}$ & 480 & $61,7-70,6$ & 8,9 & 1,9 & 1,17 & $6,5 \mathrm{e}-007$ & $1,1 \mathrm{e}-006$ \\
\hline$K_{2}$ & -1100 & $70,6-98,2$ & 27,6 & 2,3 & 1,53 & $8 \mathrm{e}-007$ & $1,25 \mathrm{e}-006$ \\
\hline $\begin{array}{c}\text { Кындалская } \\
\text { Kyndalskaya } k n K_{1-2}\end{array}$ & 1990 & $98,2-108,4$ & 10,2 & 2,3 & 1,53 & $8 \mathrm{e}-007$ & $1,25 \mathrm{e}-006$ \\
\hline $\begin{array}{c}\text { Йорекская } \\
\text { Iorekskaya ir } K_{1}\end{array}$ & 437 & $108,4-116$ & 7,6 & 2,5 & 1,69 & $8 \mathrm{e}-007$ & $1,3 e-006$ \\
\hline$K_{1}$ & - & $116-118,2$ & 2,2 & - & - & - & - \\
\hline $\begin{array}{c}\text { Чемчукинская } \\
\text { Chemchukinskaya } \mathrm{cm} K_{1}\end{array}$ & 581 & $118,2-127,5$ & 9,3 & 2,5 & 1,69 & $8 \mathrm{e}-007$ & $1,3 e-006$ \\
\hline $\begin{array}{c}\text { Чагдамынская } \\
\text { Chagdaminskaya } c g K_{1}\end{array}$ & 382 & $127,5-136,4$ & 8,9 & 2,58 & 1,76 & $8 \mathrm{e}-007$ & $1,3 \mathrm{e}-006$ \\
\hline $\begin{array}{c}\text { Ургальская } \\
\text { Urgalskaya } u r J_{3}-K_{1}\end{array}$ & 398 & $136,4-150,8$ & 14,4 & 2,52 & 1,71 & $8 \mathrm{e}-007$ & $1,3 \mathrm{e}-006$ \\
\hline
\end{tabular}

* - данные литолого-стратиграфических разбивок взяты из монографии [3]; ** - в качестве основы использована Шкала геологическо20 врелени [18]; *** - плотность пород выделенных свит и толш, принята по материалал монографии [3]. Светло-серой заливкой показаны времена накопления потенииально нефтегазоматеринских свит и их параметрическое описание, серой- перерывы осадконакопления и размывы меловых и палеоген-неогеновых отложений.

* - the data of lithological and stratigraphic differentiation are taken from the monograph [3]; ** - the geological time Scale is used as a basis [18]; *** - the rock density of the selected suites and strata are taken from the monograph [3]. Light-gray fill shows the accumulation times of potentially oil and gas source suites and their parametric description, gray fill shows sedimentation breaks and erosion of Cretaceous and Paleogene-Neogene deposits

Таблица 2. Сопоставление измеренных и расчетных геотемпе ратур в скважинах

Table 2. Comparison of measured and calculated temperatures in wells

\begin{tabular}{|c|c|c|c|c|}
\hline $\begin{array}{c}\text { Глубина, } \\
\text { м } \\
\text { Depth, m }\end{array}$ & $\begin{array}{c}\text { Измеренные } \\
\text { температуры, } \\
{ }^{\circ} \mathrm{C} \\
\text { Measured } \\
\text { temperatures, } \\
{ }^{\circ} \mathrm{C}\end{array}$ & $\begin{array}{c}\text { Способ из- } \\
\text { мерения } \\
\text { Measure- } \\
\text { ment } \\
\text { method }\end{array}$ & $\begin{array}{c}\text { Расчетные } \\
\text { температу- } \\
\text { ры, }{ }^{\circ} \mathrm{C} \\
\text { Calculated } \\
\text { temperatu- } \\
\text { res, }{ }^{\circ} \mathrm{C}\end{array}$ & $\begin{array}{c}\text { Разница расчет- } \\
\text { ных и измерен- } \\
\text { ных температур, } \\
\text { 'C } \\
\text { Difference between } \\
\text { calculated and } \\
\text { measured tempe- } \\
\text { ratures, }{ }^{\circ} \mathrm{C}\end{array}$ \\
\hline \multicolumn{5}{|c|}{ Скважина 1A/Well 1A } \\
\hline 1888 & 99 & \multirow{2}{*}{ по ОСВ } & 102 & +3 \\
\hline 2196 & 114 & & 111 & -3 \\
\hline \multicolumn{4}{|c|}{$\begin{array}{c}\text { Среднеквадратическое отклонение («невязка»), }{ }^{\circ} \mathrm{C} \\
\text { Mean-square deviation ( «residual error»), }{ }^{\circ} \mathrm{C}\end{array}$} & \pm 3 \\
\hline \multicolumn{4}{|c|}{$\begin{array}{c}\text { Расчетная плотность теплового потока, мВт } / \mathrm{m}^{2} \\
\text { Calculated heat flow, } \mathrm{mW} / \mathrm{m}^{2}\end{array}$} & 49 \\
\hline \multicolumn{5}{|c|}{ Скважина 1C/Well 1C } \\
\hline 1211 & 83 & \multirow{3}{*}{ по ОСВ } & 81 & -2 \\
\hline 1263 & 83 & & 83 & 0 \\
\hline 1355 & 84 & & 86 & +2 \\
\hline \multicolumn{4}{|c|}{$\begin{array}{l}\text { Среднеквадратическое отклонение («невязка»), }{ }^{\circ} \mathrm{C} \\
\text { Mean-square deviation ( } \text { residual error»), }{ }^{\circ} \mathrm{C}\end{array}$} & \pm 2 \\
\hline \multicolumn{4}{|c|}{$\begin{array}{c}\text { Расчетная плотность теплового потока, мBт/ } / \mathrm{m}^{2} \\
\text { Calculated heat flow, } \mathrm{mW} / \mathrm{m}^{2}\end{array}$} & 45 \\
\hline
\end{tabular}

Достоверность результатов моделирования, выполненного на скважинах $1 \mathrm{~A}$ и $1 \mathrm{C}$ Кындалского грабена, подтверждается согласованностью полученных расчетных значений плотности теплового потока 45 и $49 \mathrm{mBт} / \mathrm{M}^{2}$ (табл. 2) с порядком расчет- ных значений плотности теплового потока на скважинах B1, E1 и Е2 Переяславского грабена Среднеамурской впадины (48-56 мВт/м²) [23]. Результаты моделирования не противоречат трем значениям теплового потока, измеренным в пределах Буреинского бассейна $(40,56$ и 90$) \mathrm{MBT} / \mathrm{M}^{2}$ [24], и диапазону значений теплового потока в бассейне Bide-Santang (46-59 мВт/ $\left./ \mathrm{m}^{2}\right)$ [25].

Результирующие графики истории погружения и геотемператур осадочных комплексов Кындалского грабена представлены на рис. 2.

Интересно отметить кратковременное, но характерное охлаждение осадочного разреза, начиная с 108 млн лет назад (пиковое «провисание» изотерм, рис. 2), обусловленное как высокой скоростью накопления кындалской свиты, так и ее последующей мощной денудацией.

Рассеянное органическое вещество (РОВ) изучаемых осадочных комплексов преимущественно гумусового типа, поэтому нижняя температурная граница вхождения в верхнюю зону газообразования (ВЗГ) принята $60{ }^{\circ} \mathrm{C}$, в главную зону нефтеобразования (ГЗН) $-95^{\circ} \mathrm{C}$, в нижнюю зону газообразования (НЗГ) $-130{ }^{\circ} \mathrm{C}$.

В соответствии с температурной градацией зон интенсивной генерации УВ, используя полученную табличную базу термической истории свит и ее графическое представление (рис. 2), проведена оценка степени реализации генерационного потенциала талынджанской, ургальской, чагдамынской, чемчукинской и йорекской свит. Выполнена 

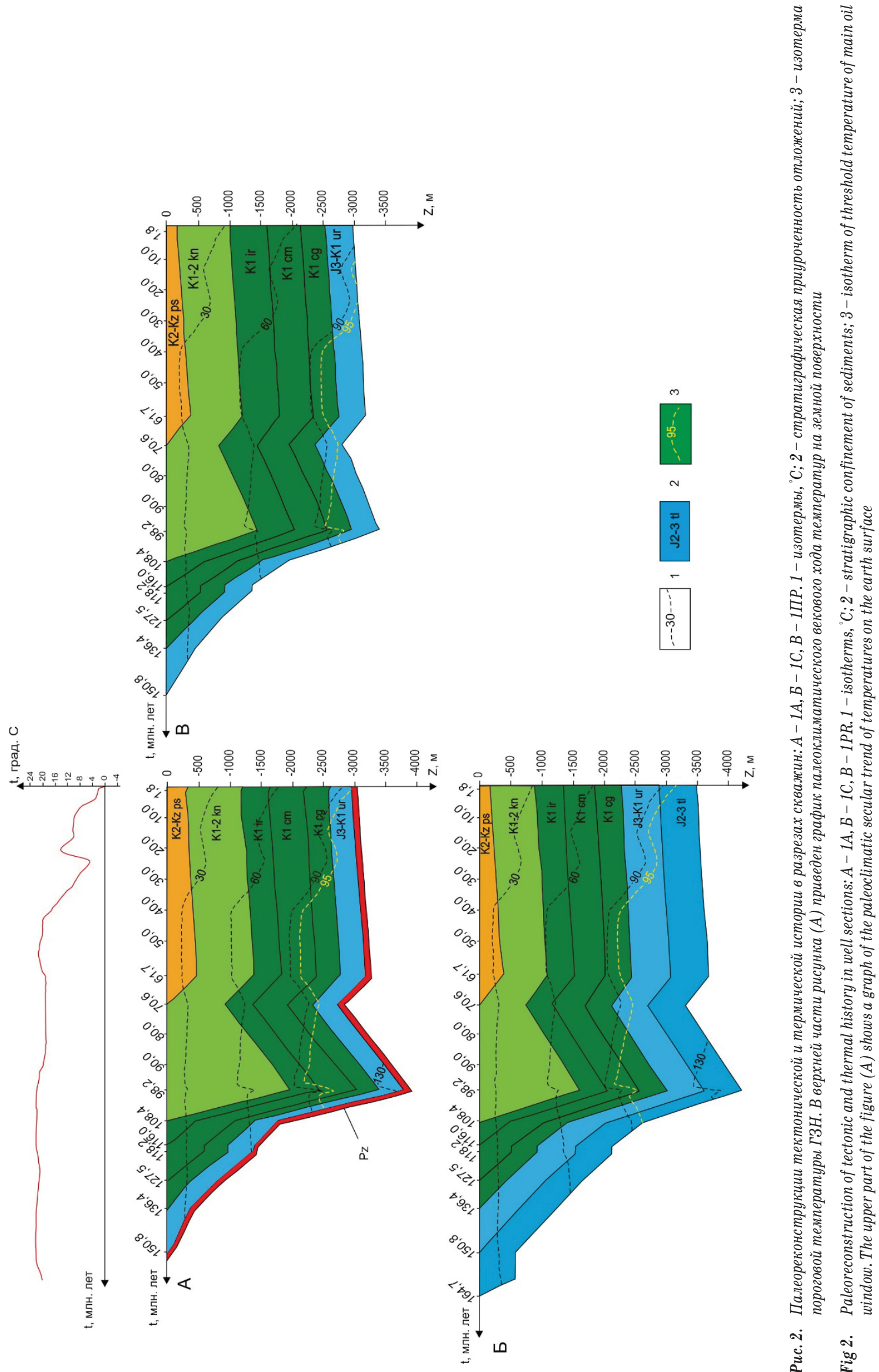
экспресс-оценка плотности генерации УВ - рассчитан интегральный показатель $R$.

\section{Результаты исследований}

Сводные данные экспресс-оценки по интегральному температурно-временному показателю генерации УВ $(R)$ талынджанской, ургальской, чагдамынской, чемчукинской и йорекской свит приведены в табл. 3.

Анализ истории погружения и геотемператур (рис. 2), интегральных оценок генерации нефти и газа (табл. 3) показывает, что на протяжении истории погружения Буреинского бассейна в пределах Кындалского грабена генеращия УВ могла происходить в тальнджанской, ургальской, чагдалььнской, чемчукинской и йорекской свитах. Кындалская свита за всю свою историю практически не входила в ГЗН, лишь эпизодически, незначительно, подошвой достигала верхов ВЗГ.

Около 126,0 млн лет назад породы талынджанской свиты вошли в ВЗГ. Благоприятные геотемпературные условия для генерации нефти отложениями талынджанской свиты (ГЗН) наступили 107 млн лет назад. Затем, начиная с 98,2 млн лет назад, свита вошла в НЗГ. Результаты расчётов свидетельствуют о том, что с 87,5 млн лет назад по настоящее вреля в отложениях тальнджанской свиты генерируется нефть (ГЗН).

Около 114,0-112,0 млн лет назад породы ургальской свиты вошли в ВЗГ. Затем, приблизительно 103,0-101,0 млн лет назад, ургальская свита достигла ГЗН. Наибольшая длительность фазы генерации нефти ургальской свитой наблюдается в районе скважины $1 \mathrm{~A}$, где отложения продолжали

Таблица 3. Экспресс-оценка генерации углеводородов (температурно-вреленные интервалы ВЗГ, НЗГ и ГЗН)

Table 3. Rapid assessment of hydrocarbon generation (temperature and time intervals of upper gas formation zone, lower gas formation zone and main oil generation zone)

\begin{tabular}{|c|c|c|c|c|c|c|}
\hline $\begin{array}{c}\text { Потенциально } \\
\text { материнская сви- } \\
\text { та } \\
\text { Potentially } \\
\text { source suite }\end{array}$ & $\begin{array}{c}\text { Экспресс-рас- } \\
\text { чет плотности } \\
\text { генерации газа } \\
(R), \text { усл. ед } \\
\text { Rapid calcula- } \\
\text { tion of gas gen- } \\
\text { eration density, } \\
\text { c.u. }\end{array}$ & $\begin{array}{c}\text { Период работы палеоочага } \\
\text { генерации газа, млн лет } \\
\text { назад; максимальные гео- } \\
\text { температуры, }{ }^{\circ} \mathrm{C} \\
\text { Working period of gas } \\
\text { paleokitchen, million years } \\
\text { ago; the maximum } \\
\text { geotemperatures, }{ }^{\circ} \mathrm{C}\end{array}$ & $\begin{array}{c}\text { Время работы } \\
\text { палеоочагов } \\
\text { генерации га- } \\
\text { за, млн лет } \\
\text { Working time } \\
\text { of gas paleo- } \\
\text { kitchen, mil- } \\
\text { lion years }\end{array}$ & $\begin{array}{c}\text { Экспресс-расчет } \\
\text { плотности гене- } \\
\text { рации нефти }(R), \\
\text { усл. ед } \\
\text { Rapid calculation } \\
\text { of oil generation } \\
\text { density, c.u. }\end{array}$ & $\begin{array}{c}\text { Период работы палеоочага } \\
\text { генерации нефти, млн лет на- } \\
\text { зад; максимальные геотемпе- } \\
\text { ратуры, }{ }^{\circ} \mathrm{C} \\
\text { Working period of oil paleo- } \\
\text { kitchen, million years ago; } \\
\text { maximum geotemperatures, }{ }^{\circ} \mathrm{C}\end{array}$ & $\begin{array}{c}\text { Время работы } \\
\text { палеоочагов ге- } \\
\text { нерации неф- } \\
\text { mu, млн лет } \\
\text { Working time of } \\
\text { oil paleokitchen, } \\
\text { million years }\end{array}$ \\
\hline \multicolumn{7}{|c|}{ Скважина 1A/Well 1A } \\
\hline $\begin{array}{l}\text { Ургальская } \\
\text { Urgalskaya }\end{array}$ & 17 & $\begin{array}{c}112,0-103,0 ; 94 \\
96,0-94,0 ; 132(\mathrm{H} 3 \Gamma) \\
6,0-0,0 ; 94 \\
\end{array}$ & 17 & 128 & $\begin{array}{c}103,0-96,0 ; 13094,0-6,0 \\
120\end{array}$ & 96 \\
\hline $\begin{array}{l}\text { Чагдамынская } \\
\text { Chagdaminskaya }\end{array}$ & 47 & $\begin{array}{c}107,0-102,0 ; 83 \\
77,5-67,0 ; 92 \\
35,0-0,0 ; 94 \\
\end{array}$ & 50 & 63 & $\begin{array}{c}102,0-77,5 ; 12167,0-35,0 ; \\
107\end{array}$ & 56 \\
\hline $\begin{array}{c}\text { Чемчукинская } \\
\text { Chemchukinskaya }\end{array}$ & 87 & $\begin{array}{c}105,0-99,0 ; 93 \\
87,5-0,0 ; 93\end{array}$ & 94 & 12 & $99,0-87,5 ; 107$ & 12 \\
\hline $\begin{array}{l}\text { Йорекская } \\
\text { Iorekskaya }\end{array}$ & 60 & $\begin{array}{c}103,0-74,0 ; 91 \\
71,0-28,0 ; 78\end{array}$ & 72 & - & - & - \\
\hline \multicolumn{7}{|c|}{ Скважина 1C/Well 1C } \\
\hline $\begin{array}{l}\text { Талынджанская } \\
\text { Talindzhanskaya }\end{array}$ & 31 & $\begin{array}{c}126,0-107,0 ; 87 \\
98,2-87,5 ; 139(\text { НЗГ) }\end{array}$ & 30 & 125 & $\begin{array}{c}107,0-98,2 ; 13087,5-0,0 \\
130\end{array}$ & 96 \\
\hline $\begin{array}{l}\text { Ургальская } \\
\text { Urgalskaya }\end{array}$ & 42 & $\begin{array}{c}14,0-103,0 ; 92 \\
71,0-69,0 ; 94 \\
32,0-0,0 ; 94\end{array}$ & 45 & 80 & $\begin{array}{c}103.0-71.0 ; 12369.0-32.0 \\
110\end{array}$ & 69 \\
\hline $\begin{array}{l}\text { Чагдамынская } \\
\text { Chagdaminskaya }\end{array}$ & 72 & $\begin{array}{c}107,0-101,0 ; 87 \\
84,5-61,7 ; 94 \\
48,0-0,0 ; 94 \\
\end{array}$ & 77 & 31 & $\begin{array}{c}101.0-84.5 ; 10961.7-48.0 ; \\
95\end{array}$ & 30 \\
\hline $\begin{array}{c}\text { Чемчукинская } \\
\text { Chemchukinskaya }\end{array}$ & 93 & $105,0-7,0 ; 95$ & 98 & - & - & - \\
\hline $\begin{array}{l}\text { Йорекская } \\
\text { Iorekskaya }\end{array}$ & 40 & $\begin{array}{c}102,0-77,5 ; 86 \\
65,0-36,0 ; 67 \\
\end{array}$ & 54 & - & - & - \\
\hline \multicolumn{7}{|c|}{ Скважина 1ПP/Well 1PR } \\
\hline $\begin{array}{l}\text { Ургальская } \\
\text { Urgalskaya }\end{array}$ & 50 & $\begin{array}{c}112,0-101,0 ; 92 \\
76,0-68,0 ; 94 \\
35,0-0,0 ; 94\end{array}$ & 54 & 62 & $\begin{array}{c}101.0-76.0 ; 10968.0-35.0 \\
106\end{array}$ & 58 \\
\hline $\begin{array}{c}\text { Чагдамынская } \\
\text { Chagdaminskaya }\end{array}$ & 80 & $\begin{array}{c}107,0-99,0 ; 89 \\
91,0-62,0 ; 94 \\
48,0-0,0 ; 94\end{array}$ & 85 & 21 & $99.0-91.0 ; 9862.0-48.0 ; 96$ & 22 \\
\hline $\begin{array}{c}\text { Чемчукинская } \\
\text { Chemchukinskaya }\end{array}$ & 88 & $105,0-3,0 ; 86$ & 102 & - & - & - \\
\hline $\begin{array}{l}\text { Йорекская } \\
\text { Iorekskaya }\end{array}$ & 37 & $\begin{array}{c}101,0-80,0 ; 71 \\
67,0-35,0 ; 69\end{array}$ & 53 & - & - & - \\
\hline
\end{tabular}


генерировать нефть в период с 103 до 6 млн лет назад. Раньше ургальская свита вышла из ГЗН в районе скважины 1 ПР, около 35 млн лет назад. В районе скважины $1 \mathrm{C}$ главная фаза нефтегенерации ургальской свитой завершилась 32 млн лет назад. В настоящее вреля отложения ургальской свиты в пределах территории исследований являются газопроизводящили (ВЗГ).

Около 107,0 млн лет назад чагдалынская свита вошла в ВЗГ. Благоприятные условия для генерации нефти отложениями чагдамынской свиты сформировались приблизительно 102-99 млн лет назад. Затем, около 91,0-77,5 млн лет назад, под влиянием тектонического (общее воздымание территории и последующий размыв) и палеоклиматического факторов, чагдамынская свита вышла из ГЗН. Вторая волна входа в ГЗН, обусловленная нарастанием мощности перекрывающей осадочной толщи, наступила приблизительно 69-62 млн лет назад. Раньше чагдамынская свита вышла из «нефтяного окна» в районе скважин 1ПР и $1 \mathrm{C}$, около 48 млн лет назад. В районе скважины 1А главная фаза нефтегенерации отложениями чагдамынской свиты завершилась 35 млн лет назад. В настоящее вреля породы чагдалынской свиты в пределах территории исследований являются га зопроизводящили.

Около 105,0 млн лет назад челчукинская свита вошла в ВЗГ. В период 99,0-87,5 млн лет назад в районе скважины $1 \mathrm{~A}$ отложения чемчукинской свиты генерировали нефть (ГЗН). Фаза нефтеобразования в отложениях чемчукинской свиты в районе скважин $1 \mathrm{C}$ и $1 П Р$ места не имела. Приблизительно 105,0-87,5 млн лет назад чемчукинская свита начала генерировать газ. Раньше чемчукинская свита вышла из ВЗГ в районе скважины 1С, 7 млн лет назад. В районе скважины 1ПР фаза газообразования завершилась 3 млн лет назад. В настоящее время в районе скважины 1 А отложения чемчукинской свиты продолжают генерировать газ.

Около 103,0-101,0 млн лет назад отложения йорекской свиты достигли температуры $60{ }^{\circ} \mathrm{C}$ (ВЗГ). Затем, около 80,0-74,0 млн лет назад, йорекская свита вышла из ВЗГ. Вторая волна входа в ВЗГ наступила приблизительно 71-65 млн лет назад. Раньше йорекская свита вышла из ВЗГ в районе скважин $1 \mathrm{C}$ и $1 П Р$, около 36-35 млн лет назад. Наибольшая длительность фазы генерации газа йорекской свитой наблюдается в районе скважины 1А, где отложения продолжали генерировать газ в период с 71 до 28 млн лет назад.

\section{Обсуждение результатов}

Наибольшая продолжительность фазы нефтеобразования (ГЗН) в Кындалском грабене наблюдается в тальнджанскол очаге генерации нефти 96 млн лет, очаг характеризуется максимальным значением плотности генерации нефти $R=125$ усл. ед (табл. 3). Соизмеримо долго, по геотемпературному критерию, «работает» в пределах грабена ургальский очаг генерации нефти, продолжительностью от 58 до 96 млн лет, $R=62-128$ усл. ед. Продолжительность фазы генерации жидких УВ чагдомынским очагом составила от 22 до 56 млн лет, $R=21-63$ усл. ед. Вклад в генерацию нефти чемчукинскил очагом мал, продолжительность генерации жидких УВ - 12 млн лет, $R=12$ усл. ед. На сегодняшний день геотемпературные условия генерации жидких УВ сохраняются для талынджанского очага.

Наибольшая фаза газообразования (ВЗГ) наблюдается в чемчукинскол очаге генерации - от 94 до $102 \mathrm{млн} \mathrm{лет,} \mathrm{очаг} \mathrm{характеризуется} \mathrm{макси-}$ мальным значением плотности генерации газа $R=87-93$ усл. ед. Продолжительность периодов газогенерации, выделенных по геотемпературному критерию, чагдолынским, йорекскил и ургальским очагами составила 50-85 млн лет $(R=47-80)$, $53-72$ млн лет $(R=37-60)$ и $17-54$ млн лет $(R=17-50)$, соответственно. Вклад в генерацию газа тальнджанскил очагом невелик, продолжительность периода газообразования $30 \mathrm{млн} \mathrm{лет,}$ $R=31$ усл. ед.

Вероятность очагов генерации УВ, выделенных по геотемпературному критерию, не противоречит результатам испытаний глубоких скважин на исследуемой территории. Непромышленные притоки нефти получены при испытании ургальской свиmы, плёнки нефти - при испытании челчукинской cвиты.

Повышенные газопоказания зафиксированы при испытании чемчукинской, чагдомынской и ургальской свит. По данным бурения скважины $1 \mathrm{~A}$ получен промышленный приток газа из кындалской свиты. Вполне вероятно, что углеводороды, генерируемые нижнемеловыми комплексами, могли мигрировать и аккумулировать в тектонически экранированных ловушках, образовавшихся во фронте Адниканского надвига (рис. 1).

Сопоставительным анализом результатов настоящей работы, выполненной с использованием российского колплекса палеотемпературного моделирования TeploDialog, с предшествующей оценкой территории исследований, выполненной ранее с применением илпортной систель PetroMod, установлено, что термический режим прогнозируемых очагов генерации УВ (продолжительность периодов нефте- и газообразования, максимальные температуры периодов интенсивной генерации нефти и газа) отличается несущественно. Для примера сопоставления ниже представлена оценка термического режима очагов генерации УВ в районе скважины $1 \mathrm{~A}$, полученная ранее с использованием системы Petromod [9].

Для отложений ургальской свиты: период ВЗГ - 128-110 млн лет назад; периоды ГЗН 110-100 млн лет назад, с 91 млн лет назад по настоящее время; период НЗГ - 100-91 млн лет назад.

Для отложений чагдолынской свиты: периоды ВЗГ - 119-106 млн лет назад, 75-67 млн лет на- 
зад, с 35 млн лет назад по настоящее время; периоды ГЗН - 106-75 млн лет назад, 67-35 млн лет назад.

Для отложений чемчукинской свиты: периоды ВЗГ - 110-100 млн лет назад; с 85 млн лет назад по настоящее время; период ГЗН - 100-85 млн лет назад.

Для отложений йорекской свиты: период ВЗГ 105-20 млн лет назад. Фаза нефтеобразования места не имела.

Если провести сопоставление результатов ТеploDialog и PetroMod по всем трем скважинам (1A, $1 \mathrm{C}$ и 1ПР), то перечни выделенных по геотемпературному критерию очагов генерации нефти ( $m a$ льнджанский, ургальский, чагдолынский) и очагов газогенерации (ургальский, чагдольнский, чемчукинский, йорекский) полностью совпадают.

Заметное отличие результатов моделирования TeploDialog и PetroMod состоит в том, что в системе PetroMod получены периоды ВЗГи НЗГ более широкие. По-видимому, это обусловлено разными подходами к определению граничных условий при моделировании тектонической и тепловой истории отложений осадочного бассейна, о чем говорилось в разделах введения и методики исследований. Вместе с тем, можно отметить, что рассчитанные в $\mathrm{Te}$ ploDialog значения плотности глубинного теплового потока (45-49 мВт/ $\left.\mathrm{M}^{2}\right)$ согласуются со значениями современной плотности теплового потока, полученными с помощью PetroMod (48-49 мВт/м²).

\section{СПИСОК ЛИТЕРАТУРЫ}

1. Маргулис Л.С. Нефтегазоперспективные толщи Дальнего Востока России // Нефтегазовая геология. Теория и практика. 2012. - T. 7. - № 4. URL: http://www.ngtp.ru/rub/2/65_ 2012.pdf (дата обращения 01.08.2018)

2. Razvozjaeva E.P., Kirillova G.L., Prokhorova P.N. Comparative analysis of fragments of the Mesozoic East Asian continental margin: The Kyndal (Bureya Basin, Russia) and Suibin (Sanjiang Basin, China) Troughs // Russian Journal of Pacific Geology. 2014. - V. 8. - № 6. - P. 404-422.

3. Осадочные бассейны Востока России. Т. 4. Буреинский осадочный бассейн: геолого-геофизическая характеристика, геодинамика, топливно-энергетические ресурсы / гл. ред. А.И. Ханчук, отв. ред. Г.Л. Кириллова. - Владивосток: Дальнаука, 2012. $-360 \mathrm{c}$.

4. Hantschel T., Kauerauf A.I. Fundamentals of basin and petroleum systems modeling. - Heidelberg: Springer, 2009. - 476 p.

5. Galushkin Yu. Non-standard Problems in Basin Modelling. Switzerland: Springer, 2016. - 274 p.

6. Reconstruction of the Cenozoic History of Hydrocarbon Fluids from Rifting Stage to Passive Continental Margin Stage in the Huizhou Sag, the Pearl River Mouth Basin / Yajun Li, Shu Jiang, Zhenglong Jiang, Hao Liu and Bingxi Li // Geofluids. - 2017. UNSP 4358985. - $32 \mathrm{p}$.

7. Galushkin Yu.I., Sitar K.A., Kunitsyna A.V. Numerical modeling of the organic matter transformation in the sedimentary rocks of the northeastern Sakhalin shelf // Oceanology. - 2011. V. 51. - № 3. - P. 491-501.

8. Historical-geological modeling of hydrocarbon generation in the mesozoic-cenozoic sedimentary basin of the Kara sea (basin modeling) / A.E. Kontorovich, L.M. Burshtein, N.A. Malyshev,

\section{Выводы}

1. Геотермия Кындалского грабена, начиная с юрского времени, благоприятствовала процессам генерации жидких углеводородов в породах осадочного чехла, которые могли начаться около 107 млн лет назад, в середине альба. Наиболее интенсивно нефтегенерация происходила в период 107-40 млн лет назад, до середины эоцена. На сегодняшний день температурные условия генерации жидких углеводородов сохраняются для талынджанского очага.

2. Наибольшая продолжительность температурных периодов, благоприятных для газообразования, наблюдается в челчукинскол очаге. В настоящее время условия генерации газа сохраняются для ургальского и чагдолынского очагов.

3. Результаты выделения по геотемпературному критерию очагов генерации нефти и очагов газогенерации, полученные с использованием систем TeploDialog и PetroMod, во многом и в основном совпадают.

4. Названные системы характеризуются разныли подходали к рассмотрению тектоно-седиментационных и термических условий генерации УВ. Поэтому результаты настоящих исследований являются дополнительной аргументацией положительных перспектив нефтегазоносности верхнеюрско-нижнемеловых отложений Буреинского бассейна.

P.I. Safronov, S.A. Gus'kov, S.V. Ershov, V.A. Kazanenkov, N.S. Kim, V.A. Kontorovich, E.A. Kostyreva, V.N. Melenevsky, V.R. Livshits, A.A. Polyakov, M.B. Skvortsov // Russian Geology and Geophysics. - 2013. - V. 54. - № 8. - P. 1179-1226.

9. Razvozzhaeva E.P., Prokhorova P.N., Lapkovskii V.V. Numerical Modeling of the Tectonic and Thermal History of the Kyndal Graben of the Bureya Basin (Far East of Russia) // Russian Journal of Pacific Geology. - 2017. - V. 11. - № 3. - P. 205-222.

10. Mesozoic-Cenozoic Climate and Neotectonic Events as Factors in Reconstructing the Thermal History of the Source-Rock Bazhenov Formation, Arctic Region, West Siberia, by the Example of the Yamal Peninsula / V.I. Isaev, A.A. Iskorkina, G.A. Lobova, V.I. Starostenko, S.A. Tikhotskii, A.N. Fomin // Izvestiya, Physics of the Solid Earth. - 2018. - V. 54. - № 2. - P. 310-329.

11. Generalization of the Rayleigh-Tikhonov stationary geothermal problem for a horizontal layer / V.I. Starostenko, R.I. Kutas, V.N. Shuman, 0.V. Legostaeva // Izvestiya, Physics of the Solid Earth. - 2006. - V. 42. - № 12. - P. 1044-1050.

12. Хант Дж. Геохимия и геология нефти и газа. - М.: Мир, 1982. $-704 \mathrm{c}$.

13. Royden L., Keen C.E. Rifting process and thermal evolution of the continental margin of eastern Canada determined from subsidence curves // Earth and Planet. Sci. Letters. - 1980. - V. 51. P. 342-361.

14. Геотермия арктических морей / М.Д. Хуторской, В.Р. Ахмедзянов, А.В. Ермаков, Ю.Г. Леонов, Л.В. Подгорных, Б.Г. Поляк, Е.А. Сухих, Л.А. Цыбуля. - М.: ГЕОС, 2013. - 232 с.

15. Искоркина А.А. Палеоклиматические факторы реконструкции термической истории нефтематеринской баженовской свиты арктического региона Западной Сибири // Известия Томского политехнического университета. Инжиниринг георесурсов. - 2016. - T. 327. - № 8. - С. 59-73. 
16. Модель катагенеза органического вещества (на примере баженовской свиты) / Л.М. Бурштейн, Л.В. Жидкова, А.Э. Конторович, В.Н. Меленевский // Геология и геофизика. - 1997. T. 38. - № 6. - С. 1070-1078.

17. Лобова Г.А., Попов С.А., Фомин А.Н. Локализация прогнозных ресурсов нефти юрско-меловых НГК Усть-Тымской мегавпадины // Нефтяное хозяйство. - 2013. - № 2. - С. 36-40.

18. Шкала геологического времени / У.Б. Харленд, А.В. Кокс, П.Г. Ллевеллин, К.А.Г. Пиктон, А.Г. Смит, Р. Уолтерс. - М.: Мир, 1985. - 140 c.

19. Yalcin M.N., Littke R., Sachsenhofer R.F. Thermal history of sedimentary basins. - Berlin: Springer Verlag, 1997. - 167 p.

20. Фомин А.Н. Катагенез органического вещества и нефтегазоносность мезозойских и палеозойских отложений Западно-Сибирского мегабассейна. - Новосибирск: ИНГГ СО РАН, 2011. $331 \mathrm{c.}$

21. Тектоно-седиментационная интерпретация данных геотермии при выявлении и оценке позднеэоценовой эрозии на арктических месторождениях углеводородов (п-ва Ямал) / В.И. Исаев, В.И. Старостенко, Г.А. Лобова, А.Н. Фомин, А.К. Исагалиева // Известия Томского политехнического университета. Инжиниринг георесурсов. - 2017. - Т. 328. - № 7. - С. 19-31.
22. Strakhov V.N., Golizdra G.Ya., Starostenko V.I. Theory and practice of interpreting potential fields: Evolution in the 20th century // Izvestiya, Physics of the Solid Earth. - 2000. V. 36. - № 9. - P. 742-762.

23. Estimation of the Oil-and-Gas Potential of Sedimentary Depression in the Far East and West Siberia Based on Gravimetry and Geothermy Data / R.Yu. Gulenok, V.I. Isaev, V.Yu. Kosygin, G.A. Lobova, V.I. Starostenko // Russian Journal of Pacific Geology. - 2011. - V. 5. - № 4. - P. 273-287.

24. Thermal structure of lithosphere in Central Asian and Pacific belts and their adjacent cratons, from data of geoscience transects / P.Yu. Gornov, M.V. Goroshko, Yu.F. Malyshev, V.Ya. Podgornyi // Russian Geology and Geophysics. - 2009. V. 50, - № 5. - P. 485-499.

25. Guo C., Qin Y., Lu L. Terrestrial heat flow and geothermal field characteristics in the Bide-Santang basin, western Guizhou, South China // Energy Exploration \& Exploitation. - 2018. V. 36. - № 5. - P. 1114-1135.

Поступила 31.10.2018 2.

\section{Информация об авторах}

Прохорова П.Н., аспирант отделения геологии Инженерной школы природных ресурсов Национального исследовательского Томского политехнического университета.

Развозжаева Е.П., кандидат геолого-минералогических наук, заведующая лабораторией тектоники осадочных бассейнов Института тектоники и геофизики им. Ю.А. Косыгина ДВО РАН.

Исаев В.И., доктор геолого-минералогических наук, профессор отделения геологии Инженерной школы природных ресурсов Национального исследовательского Томского политехнического университета. 
UDC 553.98:550.8:551.76:552.5(571.62)

\title{
GEOTHERMY AND ESTIMATION OF HYDROCARBON POTENTIAL OF THE BUREYA BASIN (RUSSIAN FAR EAST)
}

\section{Polina N. Prokhorova',}

prokhorova.polina1988@gmail.com

Elena P. Razvozzhaeva²,

rep@itig.as.khb.ru

\author{
Valeriy I. Isaev', \\ isaevvi@tpu.ru \\ 1 National Research Tomsk Polytechnic University, \\ 30, Lenin Avenue, Tomsk, 634050, Russia. \\ ${ }^{2}$ Institute of Tectonics and Geophysics named after Yu.A. Kosygin, \\ 65, Kim Y. Chen street, Khabarovsk, 680000, Russia.
}

The relevance. The Bureya sedimentary basin is the most interesting in respect of oil and gas intermountain basin of frontier mainland of Russian Far East. An upbeat assessment of prospects of oil and gas field discovery in the basin is proved by the results of previous prospecting work and scientific research.

The aim of this paper is further argumentation of hydrocarbon prospects of upper Jurassic-lower Cretaceous deposits in the Bureya basin based on the use of domestic basin modeling software TeploDialog, having original features.

Study object is middle-upper Jurassic, upper Jurassic-lower Cretaceous and Cretaceous sedimentary sequences of the Kyndal graben, the most studied structure in the Bureya fore deep. The previous investigations have revealed that the whole Jurassic-Cretaceous section of the Bureya basin is involved in oil-and-gas formation.

Methods. In the software TeploDialog the paleotemperature modeling method is implemented based on the numerical solution of heattransfer equation of a horizontally layered solid with a movable upper boundary. Mathematical model includes climatological secular trend of temperatures on the earth surface (boundary condition) and paleotemperatures from vitrinite reflectance evaluation (observational). The method does not require a priori information about the nature and magnitude of the deep heat flow, the heat flow is determined by the solution of the geothermal inversion within the framework of parametric description of the sedimentation history and the history of the thermophysical properties of sedimentary strata.

Results. The study found that geothermy of graben since Jura permitted formation of liquid hydrocarbons in the sedimentary cover rocks, which could begin about 107 million years ago, in the middle of the Alb. The most intensive oil generation took place in the period of 107-40 million years ago, until the middle of the Eocene. Temperature conditions for the generation of liquid hydrocarbons are still the same for talyndzhansky kitchen. Maximal duration of temperature periods, favourable for gas formation is observed in chemcukinsky kitchen. The conditions for gas generation are still the same for urgalsky and chegdomynsky kitchens. The results obtained using the domestic software TeploDialog and previously obtained in software PetroMod, strongly aligned. These computer programs are characterized by different approaches to consideration of tectonic-sedimentation and thermal conditions of hydrocarbon generation. Therefore, the results of this study are an additional argument for the positive prospects of oil and gas potential of the upper Jurassic-lower Cretaceous deposits of the Bureya basin.

Key words:

Upper Jurassic-lower Cretaceous deposits, geothermal mode, hydrocarbon kitchens, Bureya sedimentary basin, Russian Far East.

\section{REFERENCES}

1. Margulis L.S. Oil and gas prospective strata of Russian far East. Oil and gas geology. Theory and practice, 2012, vol. 7, no. 4. In Rus. Available at: http://www.ngtp.ru/rub/2/65_2012.pdf (accessed 1 August 2018).

2. Razvozjaeva E.P., Kirillova G.L., Prokhorova P.N. Comparative analysis of fragments of the Mesozoic East Asian continental margin: The Kyndal (Bureya Basin, Russia) and Suibin (Sanjiang Basin, China) Troughs. Russian Journal of Pacific Geology, 2014, vol. 8, no. 6, pp. 404-422.

3. Osadochnye basseyny Vostoka Rossii.Vol.4. Bureinskiy osadochny basseyn: geologo-geofizicheskaya kharakteristika, geodinamika, topliuno-energeticheskie resursy [Series «Sedimentary basins of East Russia». Vol. 4. The Bureya sedimentary basin: geologicalgeophysical characteristics, geodinamics, and fuel and energy resources]. Editor-in-chef academician A.I. Khanchuk, ed. by G.L. Kirillova. Vladivostok, Dalnauka Publ., 2012. 360 p.

4. Hantschel T., Kauerauf A.I. Fundamentals of basin and petroleum systems modeling. Heidelberg, Springer, 2009. 476 p.
5. Galushkin Yu. Non-standard Problems in Basin Modelling. Switzerland, Springer, 2016. 274 p.

6. Yajun Li, Shu Jiang, Zhenglong Jiang, Hao Liu and Bingxi Li. Reconstruction of the Cenozoic History of Hydrocarbon Fluids from Rifting Stage to Passive Continental Margin Stage in the Huizhou Sag, the Pearl River Mouth Basin. Geofluids, 2017. UNSP 4358985. $32 \mathrm{p}$.

7. Galushkin Yu.I., Sitar K.A., Kunitsyna A.V. Numerical modeling of the organic matter transformation in the sedimentary rocks of the northeastern Sakhalin shelf. Oceanology, 2011, vol. 51, no. 3, pp. 491-501.

8. Kontorovich A.E., Burshtein L.M., Malyshev N.A, Safronov P.I., Gus'kov S.A., Ershov S.V., Kazanenkov V.A., Kim N.S., Kontorovich V.A., Kostyreva E.A., Melenevsky V.N., Livshits V.R., Polyakov A.A., Skvortsov M.B. Historical-geological modeling of hydrocarbon generation in the mesozoic-cenozoic sedimentary basin of the Kara sea (basin modeling). Russian Geology and Geophysics, 2013, vol. 54, no. 8, pp. 1179-1226.

9. Razvozzhaeva E.P., Prokhorova P.N., Lapkovskii V.V. Numerical Modeling of the Tectonic and Thermal History of the Kyndal 
Graben of the Bureya Basin (Far East of Russia). Russian Journal of Pacific Geology, 2017, vol. 11, no. 3, pp. 205-222.

10. Isaev V.I., Iskorkina A.A, Lobova G.A., Starostenko V.I., Tikhotskii S.A., Fomin A.N. Mesozoic-Cenozoic Climate and Neotectonic Events as Factors in Reconstructing the Thermal History of the Source-Rock Bazhenov Formation, Arctic Region, West Siberia, by the Example of the Yamal Peninsula. Izvestiya, Physics of the Solid Earth, 2018, vol. 54, no. 2, pp. 310-329.

11. Starostenko V.I., Kutas R.I., Shuman V.N., Legostaeva O.V. Generalization of the Rayleigh-Tikhonov stationary geothermal problem for a horizontal layer. Izvestiya, Physics of the Solid Earth, 2006, vol. 42, no. 12, pp. 1044-1050.

12. Khant Dzh. Geokhimiya i geologiya nefti $i$ gaza [Geochemistry and geology of oil and gas]. Moscow, Mir Publ., 1982. 704 p.

13. Royden L., Keen C.E. Rifting process and thermal evolution of the continental margin of eastern Canada determined from subsidence curves. Earth and Planet. Sci. Letters, 1980, vol. 51, pp. 342-361.

14. Khutorskoy M.D., Akhmedzyanov V.R., Ermakov A.V., Leonov Yu.G., Podgornykh L.V., Polyak B.G., Sukhikh E.A., Tsybulya L.A. Geotermiya arkticheskikh morey [Geochemistry of the Arctic seas]. Moscow, GEOS Publ., 2013. 232 p.

15. Iskorkina A.A. Paleoclimate factors of reconstructing thermal history of the petromaternal bazhenov suite of the Arctic region in Western Siberia. Bulletin of the Tomsk Polytechnic University. Geo Assets Engineering, 2016, vol. 327, no. 8, pp. 59-73. In Rus.

16. Burshteyn L.M., Zhidkova L.V., Kontorovich A.E., Melenevskiy V.N. Model of organic matter catagenesis (on the example of Bazhenov formation). Geology and Geophysics, 1997, vol. 38, no. 6, pp. 1070-1078. In Rus.

17. Lobova G.A., Popov S.A., Fomin A.N. Localization of predicted oil resources in the Jurassic and Cretaceous hydrocarbon play of Ust'-Tym megadepression. Oil Industry, 2013, no. 2, pp. 36-40. In Rus.

18. Kharlend U.B., Koks A.V., Llevellin P.G., Pikton K.A.G., Smit A.G., Uolters R. Shkala geologicheskogo vremeni [Geologic time scale]. Moscow, Mir Publ., 1985. 140 p.
19. Yalcin M.N., Littke R., Sachsenhofer R.F. Thermal history of sedimentary basins. Berlin, Springer Verlag, 1997. 167 p.

20. Fomin A.N. Katagenez organicheskogo veshchestva i neftegazonosnost mezozoyskikh i paleozoyskikh otlozheniy Zapadno-Sibirskogo megabasseyna [Organic matter catagenesis and petroleum potential of Mesozoic and Paleozoic deposits of the West Siberian megabasin]. Novosibirsk, IPGG SB RAS Publ., 2011. 331 p.

21. Isaev V.I., Starostenko V.I., Lobova G.A., Fomin A.N., Isagalieva A.K. Tectonic-sedimentation interpretation of the geothermics data when identifying and assessing the late Eocene erosion on the Arctic hydrocarbon fields (Yamal peninsula). Bulletin of the Tomsk Polytechnic University. Geo Assets Engineering, 2017, vol. 328, no. 7, pp. 19-31. In Rus.

22. Strakhov V.N., Golizdra G.Ya., Starostenko V.I. Theory and practice of interpreting potential fields: Evolution in the 20th century. Izvestiya, Physics of the Solid Earth, 2000, vol. 36, no. 9, pp. 742-762.

23. Gulenok R.Yu., Isaev V.I., Kosygin V.Yu., Lobova G.A., Starostenko V.I. Estimation of the Oil-and-Gas Potential of Sedimentary Depression in the Far East and West Siberia Based on Gravimetry and Geothermy Data. Russian Journal of Pacific Geology, 2011, vol. 5, no. 4, pp. 273-287.

24. Gornov P.Yu., Goroshko M.V., Malyshev Yu.F., Podgornyi V.Ya. Thermal structure of lithosphere in Central Asian and Pacific belts and their adjacent cratons, from data of geoscience transects. Russian Geology and Geophysics, 2009, vol. 50, no. 5, pp. 485-499.

25. Guo C., Qin Y., Lu L. Terrestrial heat flow and geothermal field characteristics in the Bide-Santang basin, western Guizhou, South China. Energy Exploration \& Exploitation, 2018, vol. 36, no. 5, pp. 1114-1135.

Received: 31 October 2018.

\section{Information about the authors}

Polina N. Prokhorova, postgraduate, National Research Tomsk Polytechnic University.

Elena P. Razvozzhaeva, Cand. Sc., head of the Laboratory of Sedimentary Basin Tectonics, Institute of Tectonics and Geophysics named after Yu.A. Kosygin.

Valeriy I. Isaev, Dr. Sc., professor, National Research Tomsk Polytechnic University. 